\title{
Penerapan pembelajaran problem posing untuk meningkatkan kemampuan berpikir kreatif siswa kelas VIII-1 SMP Negeri 23 Malang pada pokok bahasan bangun ruang sisi datar
}

\author{
Nela Wahyu Utami, Slamet* \\ Universitas Negeri Malang, Jl. Semarang No. 5 Malang, Jawa Timur, Indonesia \\ *Penulis korespondensi, Surel: slamet.fmipa@um.ac.id
}

Paper received: 01-09-2021; revised: 15-09-2021; accepted: 30-08-2021

\begin{abstract}
This study aims to determine the process of applying problem posing learning that can improve the creative thinking skills of class VIII-1 students at SMP Negeri 23 Malang on the subject of polyhedron. This type of research is Classroom Action Research (CAR) which lasts two cycles. The instruments used in this study are validation sheets, observation sheets and test sheets. Based on the results of the study indicate that the application of problem posing learning with steps that include: the stage of apperception, the stage of delivering learning objectives, the stage of delivering motivation, the stage of understanding the material, the presentation stage, the stage of submission of questions, the stage of problem solving, and the conclusion phase creative class VIII-1 SMP Negeri 23 Malang on the subject of polyhedron with evidence in the first cycle there were 58.06 percent of students who reached the category of "good" and and increased by 25.03 percent in the second cycle to 83.09 percent students who reach the "good" category.
\end{abstract}

Keywords: problem posing; creative thinking skills; polyhedron

\begin{abstract}
Abstrak
Penelitian ini bertujuan untuk mengetahui proses penerapan pembelajaran problem posing yang dapat meningkatkan kemampuan berpikir kreatif siswa kelas VIII-1 SMP Negeri 23 Malang pada pokok bahasan bangun ruang sisi datar. Jenis penelitian ini adalah Penelitian Tindakan Kelas (PTK) yang berlangsung selama dua siklus. Instrumen yang digunakan dalam penelitian ini adalah lembar validasi, lembar observasi dan lembar tes. Berdasarkan hasil penelitian menunjukkan bahwa penerapan pembelajaran problem posing dengan langkah-langkah yang meliputi: tahap apersepsi, tahap penyampaian tujuan pembelajaran, tahap penyampaian motivasi, tahap memahami materi, tahap presentasi, tahap pengajuan soal, tahap penyelesaian soal, dan tahap kesimpulan dapat meningkatkan kemampuan berpikir kreatif siswa kelas VIII-1 SMP Negeri 23 Malang pada pokok bahasan bangun ruang sisi datar dengan bukti pada siklus I terdapat 58,06 persen siswa yang mencapai kategori "baik" dan dan meningkat sebesar 25,03 persen pada siklus II menjadi 83,09 persen siswa yang mencapai kategori "baik".
\end{abstract}

Kata kunci: problem posing; kemampuan berpikir kreatif; bangun ruang sisi datar

\section{Pendahuluan}

Pada kurikulum 2013 revisi 2017, pemerintah mengimplementasikan 4C di dalam proses pembelajaran, yaitu communication (komunikasi), collaborative (kolaborasi), critical thingking and problem solving (berpikir kritis dan pemecahan masalah), dan creativity and innovation (kreativitas dan inovasi). Artinya, aspek kreativitas merupakan salah satu fokus pemerintah saat ini di dalam pembelajaran Kurikulum 2013. Setiap siswa memiliki kemampuan berpikir kreatif yang berbeda beda, sehingga kemampuan tersebut perlu dikembangkan terutama di era globalisasi saat ini. Namun, pada kenyataannya yang terjadi pada pembelajaran matematika, berpikir kreatif merupakan suatu hal yang jarang diperhatikan (Siswono, 2004). 
Berdasarkan observasi awal dengan melakukan pengamatan selama proses pembelajaran di kelas VIII- dan wawancara kepada guru matematika kelas VIII-1 serta beberapa siswa kelas VIII dan kelas IX SMPN 23 Malang pada tanggal 12 November 2018 diperoleh informasi bahwa kemampuan berpikir kreatif siswa kelas VIII-1 SMPN 23 Malang masih kurang. Hal ini tampak dimana saat pembelajaran guru masih mendominasi pelaksanaan pembelajaran. Guru harus menyelesaikan banyak materi dalam satu semester sehingga guru lebih memilih menerapkan pembelajaran konvensional karena dirasa lebih mudah dan cepat. Guru menjelaskan materi sesuai dengan materi yang ada di LKS. Guru tidak pernah mengajarkan cara memperoleh rumus sehingga siswa cenderung menghafalkan rumus. Selama pembelajaran, siswa umumnya jarang mengajukan pertanyaan ataupun mengungkapkan pendapatnya padahal guru sudah memberikan kesempatan kepada siswa untuk bertanya dan berpendapat.

Selain itu, peneliti juga melakukan tes awal untuk mengukur kemampuan berpikir kreatif siswa dalam aspek kelancaran dan keluwesan terkait materi bangun ruang sisi datar.

\section{Gambar 1.1 Tes Awal}

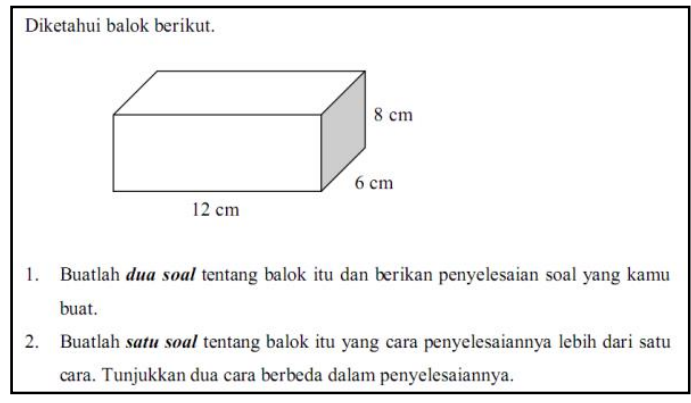

Gambar 1.2 Hasil Tes Awal Siswa A

Gambar 1.3 Hasil Tes Awal Siswa B

\begin{tabular}{|c|c|}
\hline 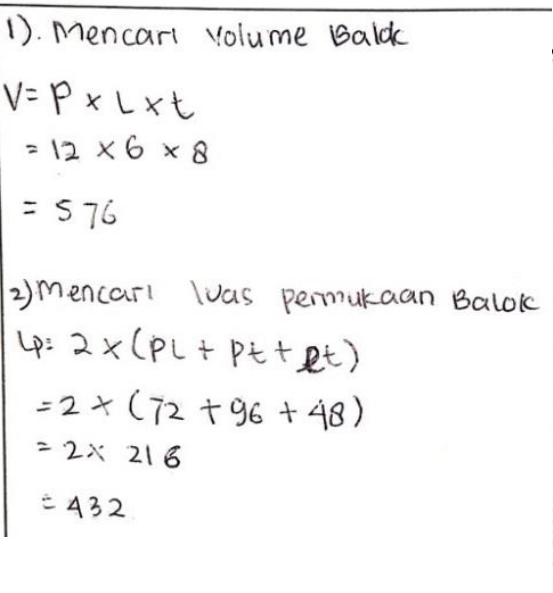 & 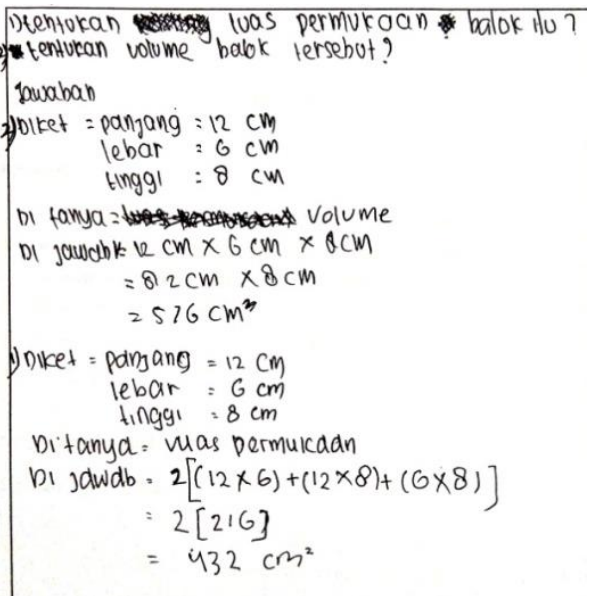 \\
\hline
\end{tabular}

Berdasarkan Gambar 1.2 terlihat bahwa siswa belum terbiasa mengajukan soal, soal yang dibuat bukanlah kalimat tanya. Sedangkan Gambar 1.3, siswa mengajukan dua soal dan 
menyelesaikannya dengan benar, hanya saja pada soal pertama siswa kurang lengkap dalam menuliskan pertanyaan. Hasil tes awal menunjukkan aspek keluwesan siswa belum muncul. Hasil tes diperoleh hanya $21,87 \%$ siswa yang memiliki kemampuan berpikir kreatif. Rendahnya tingkat kemampuan berpikir kreatif siswa ketika tes awal salah satunya disebabkan oleh tugas yang diberikan guru kepada siswa belum dapat meningkatkan berpikir kreatif, sehingga siswa belum terbiasa atau bahkan belum dapat mengerjakan soal yang sifatnya open ended.

Pembelajaran yang dapat meningkatkan kemampuan berpikir kreatif siswa adalah pembelajaran problem posing. Hal ini disebabkan dalam pembelajaran problem posing terdapat tahapan yang memberikan kesempatan kepada siswa untuk mengajukan permasalahan dan menyelesaikan permasalahan yang diajukan, merumuskan kembali masalah yang lebih kompleks dan menyelesaikan masalah tersebut (Silver, 1997). Pembelajaran dengan menerapkan problem posing dapat memfasilitasi siswa dalam mengajukan permasalahan dan mengembangkan kemampuan dalam menyelesaikan permasalahan tersebut (Bonotto, 2012).

Berdasarkan uraian permasalahan di atas maka penting untuk melakukan penelitian tentang "Penerapan Pembelajaran Problem Posing untuk Meningkatkan Kemampuan Berpikir Kreatif Siswa Kelas VIII-1 SMP Negeri 23 Malang pada Pokok Bahasan Bangun Ruang Sisi Datar".

\section{Metode}

Penelitian ini menggunakan jenis Penelitian Tindakan Kelas (PTK). Penelitian Tindakan Kelas (PTK) merupakan suatu kegiatan penelitian berkonteks kelas yang dilaksanakan untuk menyelesaikan masalah-masalah pembelajaran yang dihadapi oleh guru serta memperbaiki mutu dan hasil pembelajaran dengan mencoba menerapkan hal-hal baru (Somadayo, 2013: 20). Penelitian tindakan kelas dalam penelitian ini dilaksanakan dengan tahapan-tahapan menurut Arikunto (2010) yaitu perencanaan (planning), tindakan (action), observasi (observation), dan refleksi (reflection).

Penelitian ini dilaksanakan di SMP Negeri 23 Malang yang beralamat di Jalan Raya Tlogowaru No. 23, Malang. Waktu penelitian yakni pada semester genap tahun ajaran 2018/2019 bulan Januari-Maret 2019. Subjek penelitian ini adalah siswa kelas VIII-1 SMPN 12 Malang tahun ajaran 2018/2019 yang berjumlah 34 siswa.

Data dalam yang dikumpulkan dalam penelitian ini yaitu: (1) data hasil validasi, diperoleh dari validasi perangkat pembelajaran dan instrumen penelitian yang dilakukan oleh validator dengan menggunakan lembar validasi, (2) data hasil observasi, diperoleh dari observasi aktivitas guru dan siswa selama pembelajaran berlangsung dengan menggunakan lembar observasi aktivitas guru dan lembar observasi aktivitas siswa, (3) data kemampuan berpikir kreatif siswa, diperoleh dari hasil tes yang dilakukan disetiap akhir siklus dengan menggunakan lembar tes, dan (4) data hasil dokumentasi, diperoleh dari dokumentasi yang dilakukan selama pembelajaran berlangsung. Analisis data yang digunakan pada penelitian ini adalah teknik analisis data secara kualitatif. Miles dan Huberman (dalam Sugiyono, 2016) berpendapat bahwa teknik analisis data kualitatif yaitu dengan cara reduksi data, penyajian data, dan verifikasi /penarikan kesimpulan. 


\section{Hasil dan Pembahasan}

\subsection{Hasil}

Berdasarkan temuan-temuan pada siklus I dan siklus II, dapat diketahui bahwa penerapan pembelajaran problem posing yang dapat meningkatkan kemampuan berpikir kreatif siswa kelas VIII-1 SMP Negeri 23 Malang pada pokok bahasan bangun ruang sisi datar dapat terlaksana dengan baik. Kemampuan berpikir kreatif siswa dari siklus I mengalami peningkatan pada siklus II. Pada siklus I, hasil tes akhir siswa menunjukkan bahwa dari 31 siswa yang mengikuti tes akhir siklus I, terdapat 18 siswa tuntas dan 13 siswa tidak tuntas. Sehingga diperoleh persentase ketuntasan sebanyak 58,06\% dan persentase banyaknya siswa pada masing-masing kategori kemampuan berpikir kreatif siswa disajikan pada Tabel 1.1 berikut.

Tabel 1.1 Persentase Hasil Tes Akhir Siklus I

\begin{tabular}{lll}
\hline Kategori & Banyaknya Siswa & Persentase \\
\hline Baik Sekali & 2 & $6,45 \%$ \\
\hline Baik & 16 & $51,6 \%$ \\
\hline Cukup & 12 & $38,7 \%$ \\
\hline Kurang & 1 & $3,22 \%$ \\
\hline Sangat Kurang & - & $0,00 \%$ \\
\hline
\end{tabular}

Pada siklus II, hasil tes akhir siswa menunjukkan bahwa dari 31 siswa yang mengikuti tes akhir siklus II, terdapat 26 siswa tuntas dan 5 siswa tidak tuntas. Sehingga diperoleh persentase ketuntasan sebanyak 83,09\% dan persentase banyaknya siswa pada masingmasing kategori kemampuan berpikir kreatif siswa disajikan pada Tabel 1.2 berikut.

Tabel 1.2 Persentase Hasil Tes Akhir Siklus II

\begin{tabular}{lll}
\hline Kategori & Banyaknya Siswa & Persentase \\
\hline Baik Sekali & 6 & $19,35 \%$ \\
\hline Baik & 20 & $64,51 \%$ \\
\hline Cukup & 5 & $16,12 \%$ \\
\hline Kurang & - & $0,00 \%$ \\
\hline Sangat Kurang & - & $0,00 \%$ \\
\hline
\end{tabular}

\subsection{Pembahasan}

Pembelajaran problem posing pada pokok bahasan bangun ruang sisi datar telah diterapkan pada siswa kelas VIII-1 SMP Negeri 23 Malang. Pelaksanaan pembelajaran telah berlangsung dengan baik. Guru telah melaksanakan pembelajaran sesuai RPP yang telah dibuat, meskipun terdapat beberapa kendala pada siklus I yang kemudian diperbaiki pada siklus II. Terdapat delapan tahap pembelajaran problem posing yang dapat meningkatkan kemampuan berpikir kreatif yang dijabarkan sebagai berikut.

\subsubsection{Tahap Apersepsi}

Pembelajaran diawali dengan guru mengucapkan salam dan mengajak siswa untuk berdoa bersama. Setelah itu, guru mengecek kehadiran siswa dan meminta siswa untuk mempersiapkan perlengkapan dan peralatan yang diperlukan. Kemudian guru memberikan 
pertanyaan yang berkaitan dengan materi yang telah dipelajari sebelumnya dan menunjuk secara acak siswa untuk menjawab pertanyaan-pertanyaan tersebut.

\subsubsection{Tahap penyampaian tujuan pembelajaran}

Guru menginformasikan materi yang akan dipelajari yaitu luas permukaan dan volume bangun ruang sisi datar serta menyampaikan tujuan pembelajaran yang akan dilakukan. Setelah itu, guru menyampaikan langkah-langkah pembelajaran problem posing yang akan dilakukan. Langkah pertama yaitu siswa berdiskusi untuk menemukan rumus luas permukaan dan volume bangun ruang sisi datar, kemudian siswa mempresentasikan hasil diskusinya dan selanjutnya siswa secara individu akan membuat soal dan menyelesaikan soal yang dibuatnya. Penyampaian tujuan pembelajaran disampaikan dengan bahasa yang mudah dimengerti oleh siswa.

\subsubsection{Tahap motivasi}

Motivasi yang diberikan berkaitan dengan materi pembelajaran dengan menyajikan manfaat atau masalah kontekstual. Hal ini sesuai dengan Ningsih (2014) yang menyatakan masalah kontekstual berfungsi sebagai motivasi awal siswa dalam pembelajaran. Selanjutnya guru menyampaikan kegiatan pembelajaran yang akan dilaksanakan.

\subsubsection{Tahap memahami materi}

Pada tahap ini, guru membagi siswa menjadi 8 kelompok heterogen berdasarkan kemampuan siswa dimana 6 kelompok beranggotakan 4 siswa dan 2 kelompok beranggotakan 5 siswa. Hal ini sesuai dengan Hutagaol (2013) yang menyatakan bahwa dalam pembelajaran kelompok kecil, siswa dikelompokkan dengan anggota 4-6 siswa dan dikelompokkan secara heterogen yaitu berdasarkan kemampuan matematika siswa. Manfaat dari membentuk kelompok heterogen adalah melatih siswa untuk menerima perbedaan dan bekerjasama dengan siswa lain yang memiliki latar belakang berbeda-beda. Kemudian guru meminta siswa berkumpul dengan kelompok yang telah ditentukan. Pada siklus I dipertemuan pertama, terdapat siswa yang enggan berkumpul dengan kelompoknya karena merasa tidak cocok dengan anggota kelompoknya sehingga guru harus memberikan arahan agar siswa berkumpul bersama kelompok yang sudah ditentukan.

Setelah siswa berkumpul dan duduk dengan kelompoknya, siswa berdiskusi mengenai LKS yang telah dibagikan pada masing-masing siswa. LKS diberikan supaya siswa memahami materi dengan cara siswa menemukan konsep berdasarkan pertanyaan-pertanyaan yang terdapat di LKS yang dilanjut dengan menyelesaikan beberapa soa latihan. Pada siklus I, siswa enggan bertanya kepada guru atau teman sekelompoknya saat menemui kesulitan sehingga jawaban yang ditulis pada LKS kurang sesuai bahkan ada yang tidak melengkapi bagian LKS. Selain itu, ada beberapa siswa yang membicarakan topik lain saat berdiskusi sehingga pada siklus II guru memisahkan tempat duduk siswa yang sering membicarakan topik lain saat berdiskusi berlangsung. Hal ini sesuai dengan Mustika (2015) yang menyatakan pengaturan posisi duduk siswa dapat menghindarkan kelas dari suasana ramai. Sejalan dengan Indiyani \& Listiara (2006) yang menyatakan salah satu upaya membuat suasana efektif adalah mengatur tempat duduk. Sebelum mengerjakan latihan soal yang ada di LKS, guru memberikan contoh pengajuan soal berdasarkan situasi yang diberikan. Guru 
meminta siswa mengecek kembali hasil pengerjaan LKS mereka sebelum dipresentasikan di depan kelas.

\subsubsection{Tahap presentasi}

Guru menunjuk kelompok secara acak untuk mempresentasikan hasil diskusi kelompok. Pada pembelajaran siklus I pertemuan pertama, kelompok yang ditunjuk masih malu-malu karena siswa belum terbiasa dengan presentasi, sehingga guru memberikan motivasi kepada siswa agar siswa lebih berani lagi untuk mengutarakan atau menyampaikan hasil pengerjaan LKS mereka. Pada pertemuan kedua kelompok yang maju sudah mulai berani menyampaikan hasil pengerjaan LKS mereka. Pada siklus II ada kelompok mengajukan diri untuk mempresentasikan hasil pengerjaan LKS mereka. Setelah presentasi di depan kelas guru menawarkan kepada kelompok lain apabila memiliki jawaban yang berbeda. Selain itu, guru juga meluruskan jawaban jika terdapat jawaban yang kurang tepat. Kemudian guru memberikan penguatan dengan menjelaskan kembali secara singkat hasil presentasi tersebut. Pada pembelajaran siklus I pertemuan pertama hanya 2 kelompok yang ditunjuk maju karena alokasi waktu yang kurang baik dari guru, tetapi pada pertemuan kedua sudah lebih dari 2 kelompok yang maju. Selain itu, pada pembelajaran siklus I, guru hanya fokus memperhatikan kelompok yang presentasi, sehingga kelompok lain tidak memperhatikan dan suasana kelas sedikit gaduh. Perbaikan pada pembelajaran siklus II, guru lebih memperhatikan seluruh kelompok agar suasana kelas tetap kondusif. Sebelum masuk ke tahap pengajuan soal, guru meminta seluruh siswa mengumpulkan LKS.

\subsubsection{Tahap pengajuan soal}

As'ari (2000) menyatakan bahwa salah satu tahap dalam pembelajaran problem posing adalah memberikan kesempatan kepada siswa untuk mengajukan soal berdasarkan kondisi atau situasi yang diberikan. Sebelum guru membagikan lembar problem posing, guru meminta seluruh siswa kembali ke tempat duduknya masing-masing. Lembar problem posing berupa uraian dan waktu pengerjaan 12 menit. Pada tes ini siswa diminta untuk membuat minimal dua soal pada nomor 1 dan jika soal yang diajukan sudah memenuhi kriteria soal nomor 2 maka siswa tidak perlu mengerjakan soal nomor 2. Akan tetapi, jika belum memenuhi, maka siswa harus membuat satu soal lagi yang sesuai dengan perintah soal di nomor 2. Arsiningsih (2014) menyatakan bahwa pengajuan masalah matematika berkaitan erat dengan kemampuan berpikir kreatif siswa sehingga dengan siswa terbiasa mengajukan soal, siswa dapat memiliki kemampuan berpikir kreatif.

\subsubsection{Tahap penyelesaian soal}

Siswa tidak hanya mengajukan soal, tetapi pada tahap ini siswa harus menyelesaikan soal yang telah diajukan. Pada tahap pengajuan soal dan penyelesaian soal siswa mengerjakan secara individu. Pada pertemuan pertama siklus I, masih terdapat beberapa siswa yang mencontek saat mengerjakan lembar problem posing karena siswa masih merasa kesulitan dalam mengajukan soal. Pada pertemuan kedua siklus I sudah lebih baik, hanya ada dua siswa yang mencontek kemudian guru menegur siswa tersebut. Pada siklus II, guru lebih sering menginstruksikan kepada siswa untuk berlatih mengajukan soal pada saat aktivitas berkelompok dan presentasi sehingga pada siklus II siswa sudah mulai terbiasa mengajukan soal meskipun masih terdapat siswa yang masih membutuhkan panduan guru dalam mengajukan soal. Setelah waktu pengerjaan lembar problem posing selesai, guru meminta 
masing-masing siswa untuk mengumpulkan lembar problem posing. Selanjutnya, jika waktu masih memungkinkan guru akan membahas hasil pengerjaan problem posing, tetapi jika waktu sudah tidak memungkinkan guru akan membahas dipertemuan selanjutnya sebagai apersepsi.

\subsubsection{Tahap Kesimpulan}

Guru bersama siswa menyimpulkan materi pembelajaran pada hari itu dan siswa mencatat hasil kesimpulan dibuku catatan. Ojukwu (2014) menyatakan bahwa kesimpulan diperlukan disetiap akhir pembelajaran untuk memberikan penguatan kepada siswa terkait hal-hal penting yang terdapat pada pembelajaran agar lebih bermakna. Kemudian guru menyampaikan materi yang akan dipelajari pada pertemuan selanjutnya. Kegiatan pembelajaran diakhiri dengan guru mengajak siswa berdoa bersama dan mengucapkan salam.

\section{Simpulan}

\subsection{Kesimpulan}

Berdasarkan analisis data dan pembahasan yang telah dilakukan maka dapat disimpulkan bahwa tahapan-tahapan pembelajaran problem posing yang dapat meningkatkan kemampuan berpikir kreatif siswa di kelas VIII-1 SMP Negeri 23 Malang pada pokok bahasan bangun ruang sisi datar adalah sebagai berikut.

Langkah-langkah pembelajaran problem posing yang dapat meningkatkan kemampuan berpikir kreatif siswa pada pokok bahasan bangun ruang sisi datar yaitu:

4.1.1.Tahap apersepsi, guru menyampaikan apersepsi melalui tanya jawab terkait dengan materi yang telah dipelajari pada pertemuan sebelumnya atau materi prasyarat

4.1.2. Tahap penyampaian tujuan pembelajaran, guru menyampaikan tujuan pembelajaran yang akan dicapai,

4.1.3. Tahap motivasi, guru memberikan motivasi kepada siswa dengan mengajak siswa untuk mengamati benda-benda disekitar yang berbentuk bangun ruang sisi datar dan menyajikan masalah kontekstual yang dapat diselesaikan dengan menggunakan rumus luas permukaan dan volume bangun ruang sisi datar

4.1.4.Tahap memahami materi, guru membagi siswa menjadi beberapa kelompok heterogen dimana setiap kelompok beranggotakan 4-5 orang. Selanjutnya guru membagikan LKS kepada masing-masing siswa. LKS berguna untuk membantu siswa dalam menemukan rumus luas permukaan dan volume bangun ruang sisi datar. Pada tahap ini guru juga memberikan contoh bagaimana cara untuk mengajukan soal berdasarkan situasi yang diberikan

4.1.5. Tahap presentasi hasil diskusi LKS, guru menunjuk beberapa kelompok secara acak untuk mempresentasikan hasil diskusi kelompok mengenai luas permukaan dan volume bangun ruang sisi datar, 
4.1.6. Tahap pengajuan soal, yaitu siswa secara individu diminta untuk membuat soal sesuai dengan situasi yang diberikan pada Lembar Problem Posing,

4.1.7. Tahap penyelesaian soal, yaitu siswa menjawab soal yang dibuatnya sendiri berdasarkan situasi yang diberikan pada Lembar Problem Posing,

4.1.8. Tahap kesimpulan, yaitu guru bersama siswa menyimpulkan materi yang telah dipelajari.

Penerapan pembelajaran Problem Posing dapat meningkatakan kemampuan berpikir kreatif siswa kelas VIII-1 SMP Negeri 23 Malang pada pokok bahasan bangun ruang sisi datar. Hal ini dapat diketahui melalui peningkatan persentase ketuntasan hasil tes akhir siswa sebesar 25,03 \% dari siklus I.

\subsection{Saran}

Berdasarkan paparan data, temuan penelitian, dan pembahasan yang diperoleh dari penerapan pembelajaran problem posing yang dapat meningkatkan kemampuan berpikir kreatif siswa, peneliti memberikan saran kepada peneliti lain, antara lain:

Penerapan pembelajaran problem posing memberikan hasil yang positif terhadap peningkatan kemampuan berpikir kreatif siswa. Oleh karena itu, guru dapat menggunakan pembelajaran problem posing sebagai alternatif pembelajaran di kelas untuk meningkatkan kemampuan berpikir kreatif siswa.

Pembelajaran problem posing membutuhkan tingkat berpikir yang tinggi sehingga membutuhkan alokasi waktu yang besar. Untuk peneliti lain yang berniat menerapkan pembelajaran ini, diharapkan membuat perencanaan alokasi waktu sebaik mungkin.

Bagi peneliti selanjutnya, disarankan untuk melakukan penelitian terkait penerapan problem posing yang dapat meningkatkan kemampuan berpikir kreatif dengan materi dan indikator berpikir kreatif yang lain serta kelemahan-kelemahan yang dialami peneliti pada penelitian ini hendaknya dapat dijadikan refleksi untuk melakukan perbaikan.

Pembelajaran yang melibatkan kemampuan berpikir kreatif siswa dalam matematika perlu dilakukan untuk melatih siswa mampu melihat suatu masalah dari berbagai sudut pandang dan melahirkan banyak gagasan.

\section{Daftar Rujukan}

Asriningsih, T. M. (2014). Pembelajaran problem posing untuk meningkatkan kemampuan berpikir kreatif siswa. Gamatika, 5(1).

As'ari, Abdurrahman. (2000). Pembelajaran matematika dengan pendekatan problem posing. Buletin Pelangi Pendidikan, Vol. 2 No. 2.

Bonotto, C. (2013). Artifacts as sources for problem-posing activities. Educational studies in Mathematics, 83(1), 37-55.

Hutagaol, K. (2013). Pembelajaran kontekstual untuk meningkatkan kemampuan representasi matematis siswa sekolah menengah pertama. Infinity Journal, 2(1), 85-99.

Indiyani, N. E., \& Listiara, A. (2006). Efektivitas metode pembelajaran gotong royong (cooperative learning) untuk menurunkan kecemasan siswa dalam menghadapi pelajaran matematika (suatu studi eksperimental pada siswa di SMP 26 Semarang). Jurnal Psikologi, 3(1), 10-28.

Mustika, Z. (2015). Pentingnya peranan wali kelas dalam pembelajaran. Intelektualita, 3(1). 
Ningsih, S. (2014). Realistic mathematics education: model alternatif pembelajaran matematika sekolah. Jurnal Pendidikan Matematika, 1(2), 73-94.

Ojukwu, E. V. (2021). Adequate Lesson Plan: a Prerequisite for Effective Teaching and Learning Of Music. Awka Journal Of Research In Music And Arts (AJRMA), 9, 159-173.

Siswono, T. Y. (2004). Mendorong berpikir kreatif siswa melalui pengajuan masalah (Problem Posing). Konferensi Nasional Matematika XII, Universitas Udayana, Denpasar, Bali, 23-27.

Silver, E. A. (1997). Fostering creativity through instruction rich in mathematical problem solving and problem posing. Zdm, 29(3), 75-80.

Suhardjono, S., \& Arikunto, S. (2010). Penelitian tindakan kelas. Jakarta: Bumi Aksara.

Sumadayo, S. (2013). Penelitian tindakan kelas. Yogyakarta: Graha Ilmu.

Sugiyono, P. (2016). Metode penelitian manajemen (pendekatan kuantitatif, kualitatif, kombinasi (mixed methods), penelitian tindakan (action research, dan penelitian evaluasi). Bandung: Alfabeta Cv. 